\title{
Epidermal Growth Factor in Neonatal Mouse Urine: Maturative Effect of Thyroxine
}

\author{
J. PERHEENTUPA, J. LAKSHMANAN, AND D. A. FISHER
}

Perinatal Research Laboratories, Harbor-UCLA Medical Center, Torrance, California 90502

\begin{abstract}
Using a specific and sensitive epidermal growth factor (EGF) radioimmunoassay, we have shown measurable quantities of EGF in mouse urine during the neonatal period. Sephadex G-50 column chromatography demonstrated the presence of a single immunoreactive component at the position defined by standard EGF (mol wt 6045). Comparison of urine urea nitrogen and urine EGF levels in neonatal and adult mice showed adult values to be 3- and 16-fold higher, respectively. Kidney weights relative to body weight were similar in newborn and adult animals while kidney EGF concentration per mg protein was 2.5 -fold higher in the adult. The relative submandibular gland (SMG) weight was slightly higher in adult female mice than in the newborn, whereas SMG-EGF concentration was 15,000 -fold higher in the adult than in the newborn.

Thyroxine administration to neonatal mice from day 0 to day 6 increased urine EGF concentration 7-fold compared to control pups. Though the hormone treatment elicited a significant increase in relative SMG weight, its EGF concentration like that of the kidneys remained unchanged. The results suggest that urine EGF is subject to thyroid hormone modulation in newborn animals and that the changes in urine EGF concentration are independent of changes in SMG and renal EGF levels. (Pediatr Res 18:1080-1084, 1984)
\end{abstract}

\section{Abbreviations}

EGF, epidermal growth factor

PBS, phosphate-buffered saline

RIA, radioimmunoassay

SMG, submandibular gland

$\mathrm{T}_{4}$, thyroxine

$T_{3}$, triiodothyronine

Epidermal growth factor, a polypeptide isolated from adult mouse submandibular gland (9), stimulates experimentally growth and maturation of several tissues during fetal and neonatal development. The list of its actions includes acceleration of tooth eruption (9), eyelid opening (9), intestinal (32) and lung maturation (5), and bile duct proliferation (13). In contrast, EGF exerts an inhibition on growth of body (10), ovarian follicles $(25)$, and hair (28) in the newborn mouse. In adult animals, EGF

Received November 16, 1983; accepted March 24, 1984.

Dr. Perheentupa was on sabbatical leave from the University of Helsinki, requests for reprints should be addressed to him at Children's Hospital, SF 00290 Helsinki 29, Finland.

This work was supported by National Institutes of Health Grants HD-04270 (D. A. F.) and NS-17431A (J. L.). suppresses the immune response (35), inhibits gastric acid secretion (3), stimulates DNA synthesis $(6,12,27,38)$ accelerates wound healing $(31,40)$, and causes angiogenesis in the avascular corneal stroma (15). In accordance with these effects, EGF and its receptors are present in various tissues in the fetus and adult $(1,4,11,14,30,33)$. Though EGF most probably has an important physiological role, this remains undefined.

Body fluids of man (20) and mouse (21) contain variable amounts of EGF. In particular, urinary concentrations are very high $(21,41)$. Mouse urine EGF is structurally similar to human urine EGF or urogastrone (18). In addition to their similar amino acid sequences, both exhibit similar biological activities including inhibition of gastric acid secretion, acceleration of eyelid opening, and stimulation of cell proliferation in culture (17).

By chromatographic analysis, mouse urine contains two immunoreactive components, a major component which co-elutes with mouse EGF standard (mol wt 6,045) and a minor component of high molecular weight, approximately 30,000 (21). The significance of the latter material is unclear. It may represent a biosynthetic precursor of EGF. The urine of male and female mice contains similar amounts of EGF (21), though its concentration in the SMG is some 15-fold higher in the male (4). It is unclear which tissues contribute to urinary EGF. Limited knowledge in this area prompted the present investigation.

This paper provides evidence for the existence in neonatal mouse urine of EGF similar in molecular size to mouse standard EGF, but in concentrations much smaller than in the adult. Moreover, urinary EGF is subject to thyroid hormone modulation during the neonatal period when SMG-EGF is insensitive to thyroid hormones. In contrast, while the kidney has been suggested to synthesize EGF (18), its EGF content appeared unresponsive to thyroid hormone.

\section{MATERIALS AND METHODS}

Animals. For studies involving adult females, Swiss-Webster mice were purchased from Simonsen Laboratories, Gilroy, CA, 5 to 7 days prior to study. They were housed two per cage on arrival, kept under controlled temperature $\left(20^{\circ} \mathrm{C}\right)$ and lighting (12-h light/12-h darkness) and provided with regular laboratory chow and water ad libitum.

Multiparous pregnant mice of known gestation were obtained from the same supplier 4-5 days before delivery and housed individually. Pups born within 14-16 h were pooled and distributed 8 pups/mother. The day of birth is considered day 0 . For thyroid hormone response studies, pups were injected subcutaneously with $\mathrm{T}_{4}(0.4 \mu \mathrm{g} / \mathrm{g}$ body weight in $5 \mu \mathrm{l} 0.001 \mathrm{~N} \mathrm{NaOH})$ daily on days 0 through 6 while control pups were injected with the same volumes of solvent. Both pups and mothers were transferred to new cages every 3 days. Cotton was added to their cages for warmth. All pups were sacrificed $24 \mathrm{~h}$ after the last injection. Spontaneously voided urine was collected from animals prior to sacrifice and stored at $-20^{\circ} \mathrm{C}$. Blood collected from 
the neck was allowed to clot at room temperature for $1 \mathrm{~h}$; serum was separated following centrifugation and stored at $-20^{\circ} \mathrm{C}$. SMGs and kidneys were removed, weighed, frozen on dry ice, and stored at $-20^{\circ} \mathrm{C}$.

Tissues from adult female mice were removed after collecting blood from the inferior vena cava. All tissues were weighed, frozen immediately on dry ice, and stored at $-20^{\circ} \mathrm{C}$.

Preparation of tissue homogenate supernatants. Both SMG and kidney tissues obtained from neonatal animals were pooled (4 or $8 /$ homogenizing vessel) and homogenized using a glassTeflon homogenizer in 4 volumes of ice-cold $0.05 \mathrm{M}$ PBS, $\mathrm{pH}$ 7.2 , containing $0.05 \% \mathrm{Na}$ azide. Adult tissues were individually processed using 9 volumes of the PBS. All tissue homogenates were spun at $100,000 \times g$ for 30 min using a Beckman 40.3-type rotor. The clear supernatants were used for EGF-RIA, and protein determination (26) using bovine serum albumin as standard. Adult tissue supernatants were suitably diluted with RIA buffer containing $0.5 \%$ bovine serum albumin (RIA grade), $0.5 \%$ normal rabbit serum, and $0.05 \% \mathrm{Na}$ azide in $0.05 \mathrm{M}$ PBS. EGFRIA was performed using a liquid phase double antibody method developed in this laboratory $(22,42)$. EGF concentrations in tissues were expressed per mg protein.

$E G F-R I A$. Upon thawing, urine samples were centrifuged and aliquots of clear urine were diluted suitably in RIA buffer and used for EGF-RIA and urea nitrogen determinations (19).

Parallelism in RIA between standard mouse SMG-EGF and urine was assessed using 8 to 10 dilutions in triplicate. Recovery studies were performed as described earlier (22). RIA results were
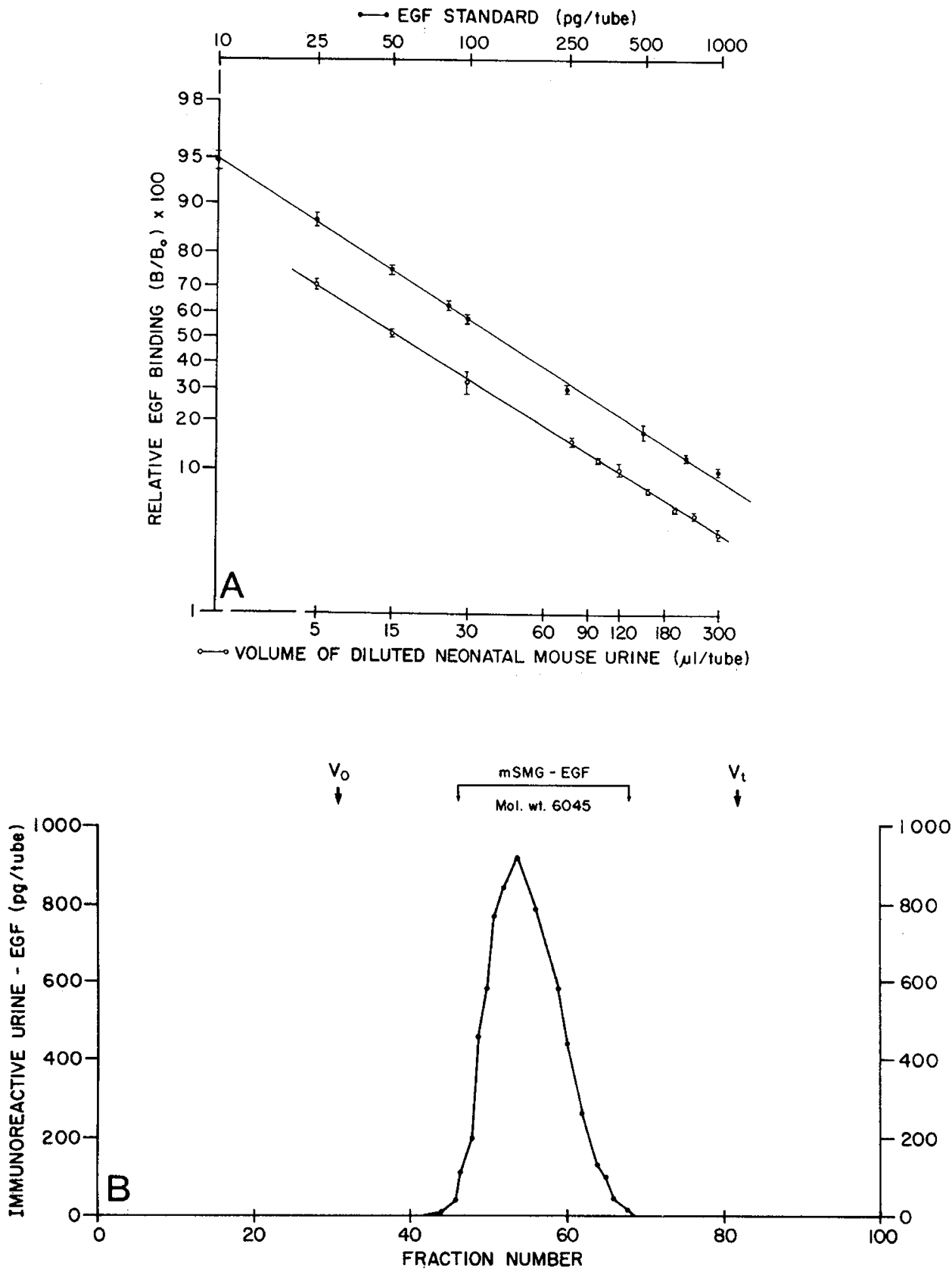

Fig. 1. Top, parallel displacement in EGF-RIA of ${ }^{125}$ I-EGF by varying amounts of standard mouse EGF and neonatal mouse urine. When six different amounts varying from none to $0.5 \mathrm{ng}$ of standard EGF per assay tube were added to neonatal mouse urine, 89 to $132 \%$ (mean 112 ) was recovered in the assay. Bottom, chromatogram of EGF-immunoreactive material in neonatal mouse urine on a Sephadex G-50 fine gel eluted with $1.0 \mathrm{M}$ acetic acid. $0.4-\mathrm{ml}$ fractions were collected. $V_{0}$, void volume (blue dextran); $V_{t}$, total volume (Na ${ }^{125} \mathrm{I}$ ). Location of the peak of mouse SMGEGF standard is indicated. 
calculated using a computer program with log logit transformation (36).

Serum thyroid hormone measurements. Following $\mathrm{T}_{4}$ treatment of the neonates, serum $\mathrm{T}_{4}$ and $\mathrm{T}_{3}$ concentrations were measured $(7,8) .{ }^{125} \mathrm{I}$-labeled $\mathrm{T}_{4}$ and $\mathrm{T}_{3}$ were purchased from New England Nuclear Corp., Boston MA.

Gel exclusion column chromatography. To assess the molecular size of neonatal mouse urinary EGF, Sephadex G-50 fine resin columns $(0.9 \times 56 \mathrm{~cm})$ were equilibrated and developed at $4^{\circ} \mathrm{C}$ with $1 \mathrm{M}$ acetic acid ( $\mathrm{pH} 2.4$ ) containing $10^{-4} \mathrm{M} \mathrm{Na}$ azide. The column was calibrated using blue dextran, $\mathrm{Na}^{125} \mathrm{I}(\sim 15,000 \mathrm{cpm})$, and unlabeled standard SMG-EGF purified by the method of Savage and Cohen (37). Recovery studies were also performed using ${ }^{125}$ I-EGF.

Aliquots of urine, suitably diluted with $1 \mathrm{M}$ acetic acid, were applied to the column in $0.5-\mathrm{ml}$ volume and eluted by descending flow $(12 \mathrm{ml} / \mathrm{h}) ; 0.4-\mathrm{ml}$ fractions were collected. The fractions were evaporated to dryness using Speed Vac (Savant Instrument Inc., New York) reconstituted in $300 \mu \mathrm{l}$ of assay buffer and assayed directly for EGF.

Statistical analysis. Student's $t$ test was used for evaluation of differences between groups. The dispersions of EGF concentrations were positively skewed and the SD values increased with the mean levels. Therefore, geometric means and mean \pm SEM intervals are presented throughout.

\section{RESULTS}

Neonatal urine and the SMG-EGF standard, applied in varying amounts to the RIA, produced parallel displacement lines (Fig. 1). In the chromatogram of neonatal urinary immunoreactive EGF on Sephadex G-50 fine gel column, only one component appeared and corresponded to standard mouse SMG-EGF of $6045 \mathrm{~mol} \mathrm{wt}$ (Fig. 1). This is similar to the major component found in adult mouse urine (21).

Urinary EGF contents are expressed both per $\mathrm{ml}$ urine and per mg urea nitrogen. The latter provides the best comparison between neonates and adult mice since it obviates variation in urine EGF concentration produced by variation in urine water content. The average EGF concentration was 16 -fold greater and the urea concentration 3-fold greater in adult urine than in newborn urine (Fig. 2).
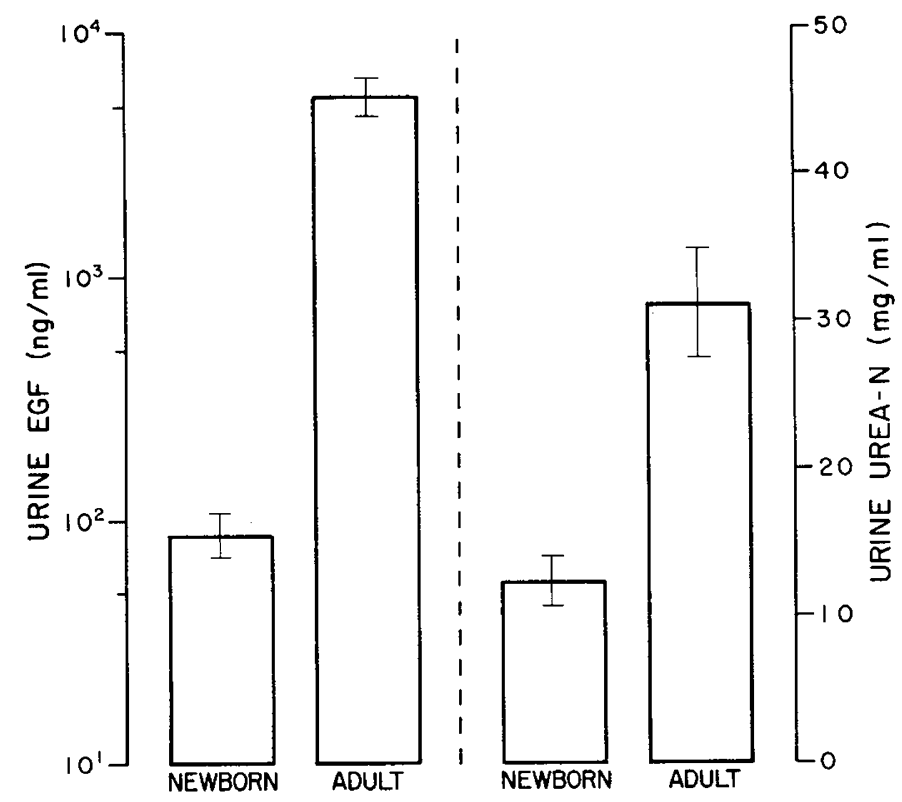

Fig. 2. Mean ( \pm SEM) urinary concentrations of EGF and urea nitrogen in 7-day-old (newborn, $n=9$ ) mice, and adult female mice $(n=10)$. Note that the scale is logarithmic for EGF and linear for urea-N. For both differences, $p<0.001$.
We also measured kidney and SMG-EGF levels to assess these organs as possible sources of urinary EGF. Kidney size relative to body size was very similar in adults and newborns, but kidney EGF levels were 2.5-fold higher in the adult (Fig. 3). Relative SMG size was slightly larger in adults $(p=0.003)$ while the adult SMG-EGF concentration exceeded the newborn value $1.5 \times 10^{4}$ fold (Fig. 3).

Effects of $T_{4}$ administration in newborn. The $\mathrm{T}_{4}$-treated pups were hyperactive, and measurements of serum $T_{4}$ and $T_{3}$ levels suggested hyperthyroid state (Table 1). However, their growth was not affected as indicated by body weight, nor were their urine urea concentrations. Thus, their hyperthyroidism was mild.

$\mathrm{T}_{4}$ treatment brought about a 7-fold increase in newborn urine EGF concentration (Fig. 4) whether expressed per $\mathrm{ml}$ urine or per mg urea nitrogen. However, even after $\mathrm{T}_{4}$ treatment, newborn urine EGF levels were less than adult values. The relative SMG weight, in contrast to kidney, was markedly increased in the $T_{4^{-}}$ treated pups. Both SMG and kidney EGF concentrations remained unchanged by hormone administration.

\section{DISCUSSION}

Though EGF has been detected in saliva $(21,29)$, milk, blood $(21,34)$, bile $(34)$, and urine $(21,23)$, very little information is presently available regarding the relative concentrations, molecular size, origin, and physiological role of EGF in these fluids. Since body fluids provide a medium of transport and exchange between various organs, a comparative study of neonatal and adult animals may provide more information on the distribution of EGF in vivo. Urine offers an easy approach to such a study because of its high EGF content and the ease of collection.

The present data demonstrate the presence of EGF of standard molecular weight $(\sim 6,045)$ in neonatal mouse urine, but in concentrations much lower than in the adult. In addition, our chromatographic profile reveals the absence of a high molecular weight EGF component $(\sim 30,000)$ in neonatal urine in contrast to its existence in adult male urine as reported by Hirata and Orth (21).

We measured the EGF concentration of SMG and the kidneys as possible contributors to urine EGF. Studies in pups and adult mice indicate that the mean increase in EGF concentration during development is only 2.5 -fold for the kidney in contrast to 15,000-fold for the SMG and about 16-fold for the urine. This nonparallelism of the increases during development suggests that SMG and the kidneys may not be major sources of urinary EGF. This is corroborated by our present finding of a 7-fold increase in urine EGF concentration during $T_{4}$ treatment of the newborn in contrast to no response in SMG-EGF concentration (a 1.3fold increase in total content) and a questionable response in kidney EGF. Further research is needed of the extent of SMG and kidney contributions to urine EGF levels in adult and developing animals.

Recent studies in this laboratory indicated that kidneys, in contrast to other organs, do not concentrate exogenously administered EGF, at least not during the 1st week of life (2). This observation suggested that kidneys are not a site of EGF uptake in newborn pups. Whether kidneys synthesize EGF during a particular stage of development is not clear. The present study also documents thyroid hormonal modulation of EGF in neonatal urine at a time when SMG contains very little EGF. The increase in relative SMG weight in hormone-treated pups indicates that, although this organ is responsive to thyroid hormone from birth, its EGF concentration is hormonally insensitive during the 1 st week of life.

During the perinatal stage, maternal milk is the principal source of exogenous EGF in the mouse. Further work is necessary to show whether thyroid hormones alter the absorption and metabolism of milk EGF in the neonate. Recent reports suggest that breast milk EGF content changes significantly in mice during various stages of lactation (2). Our initial attempt to correlate urine EGF changes with blood EGF was unsuccessful 

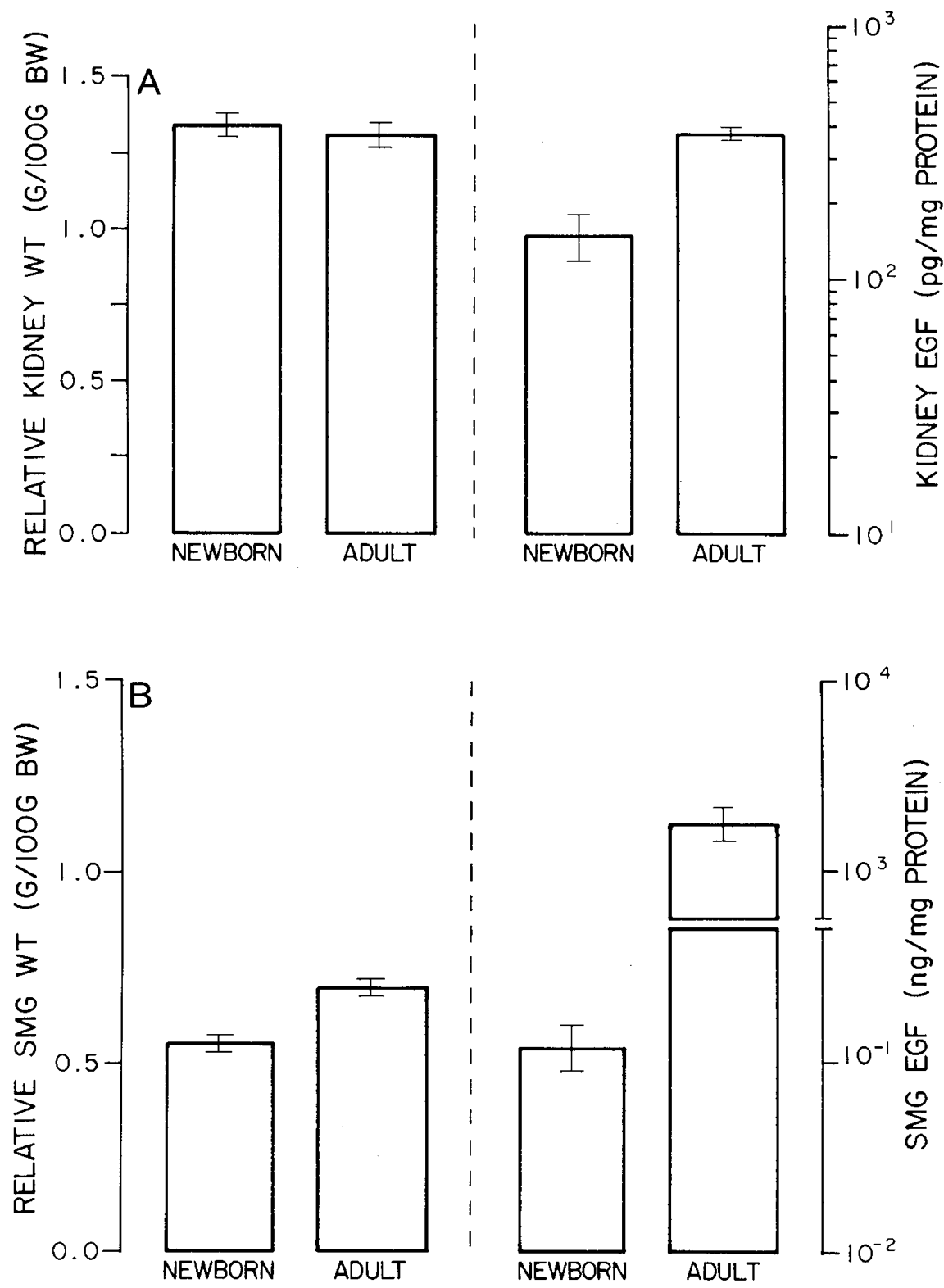

Fig. 3. Comparison between 7-day-old (newborn, $n=6)$ mice and adult female mice $(n=6)$ of relative weights and relative EGF concentrations in the kidneys (nonsignificant difference, and $\mathrm{p}=10^{-6}$, respectively) and the submandibular glands $\left(p=0.003\right.$ and $\left.p=10^{-5}\right)$. Note that the scale is linear for weight and logarithmic for EGF.

Table 1. Effect of $T_{4}$ on neonatal mice*

\begin{tabular}{|c|c|c|c|c|c|c|}
\hline \multirow[b]{2}{*}{ Treatment } & \multirow[b]{2}{*}{ Body weight } & \multicolumn{2}{|c|}{ Serum iodothyronines } & \multicolumn{2}{|c|}{$\begin{array}{l}\text { Organ weights } \\
\text { (g/100 g body wt) }\end{array}$} & \multirow{2}{*}{$\begin{array}{c}\begin{array}{c}\text { Urine urea } \\
\text { nitrogen }\end{array} \\
(\mathrm{mg} / \mathrm{ml})\end{array}$} \\
\hline & & $\begin{array}{c}\mathrm{T}_{4} \\
(\mu \mathrm{g} / \mathrm{dl})\end{array}$ & $\begin{array}{c}\mathrm{T}_{3} \\
(\mathrm{ng} / \mathrm{dl})\end{array}$ & SMG & Kidney & \\
\hline Vehicle & $4.0 \pm 0.14$ & $3.3 \pm 0.8$ & $30.5 \pm 0.2$ & $0.55 \pm 0.019$ & $1.34 \pm 0.035$ & $12.3 \pm 1.7$ \\
\hline Thyroxine & $4.1 \pm 0.07$ & $19.7 \pm 0.7$ & $50.4 \pm 5.8$ & $0.74 \pm 0.016$ & $1.44 \pm 0.12$ & $11.8 \pm 0.74$ \\
\hline$p$ & NS & $<0.001$ & NS & $<0.001$ & NS & NS \\
\hline
\end{tabular}

* Newborn pups were injected with thyroxine, $0.4 \mu \mathrm{g} / \mathrm{g}$ body wt in $5-\mu \mathrm{l}$ volume daily from birth to day 6 while control pups were injected with the same volume of vehicle. All pups were sacrificed on day 7. For each group, a total of 40 pups were used; blood was pooled in three samples. The results are mean \pm SEM.

since there were marked individual variations in serum EGF concentration within the same litter when the blood was collected from the neck as opposed to the inferior vena cava.

The effect of $\mathrm{T}_{4}$ on urine EGF appears to be highly specific in that the hormone injection did not alter urine urea nitrogen content. This rules out any alteration in relative urine EGF concentration secondary to changes in urea metabolism. The dose and timing of the urine EGF response to $T_{4}$ (from birth to 6 days of life) are similar to these aspects of the $T_{4}$ effect on EGF in skin (22) and ocular tissue of newborn mice (24). These results 


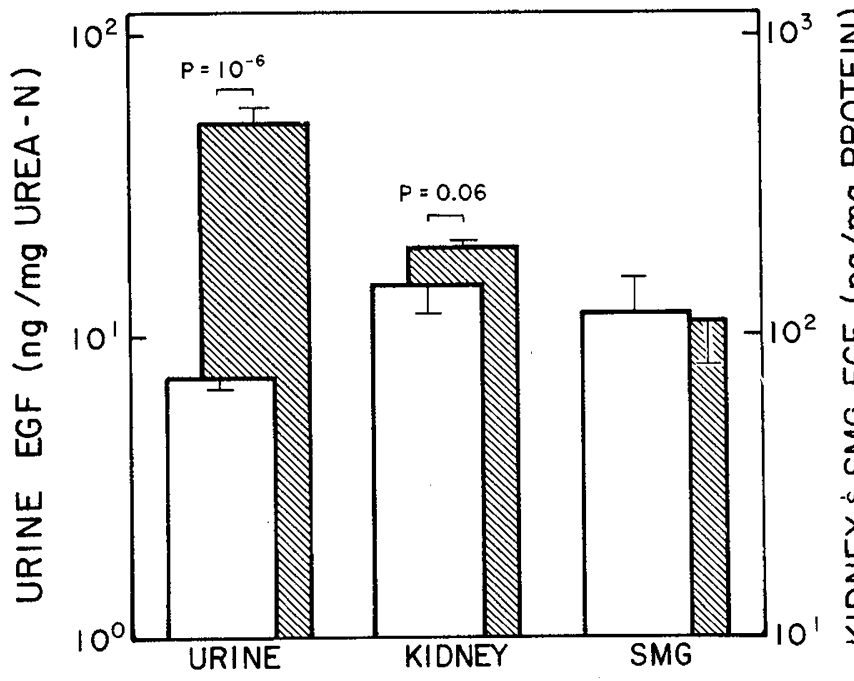

Fig. 4. Mean ( \pm SEM) relative EGF concentrations in urine (right scale) and kidneys and submandibular glands (left scale) of 7-day-old control (open bars) and thyroxine-treated (hatched bars) mice.

indicate that both tissue and body fluid EGF levels are subject to hormone modulation during the perinatal stage.

A recent study (16), based on the nucleotide sequence of mouse EGF cDNA, predicted a $128,000 \mathrm{~mol}$ wt protein precursor (comprising 1168 amino acids) of standard 6045 mol wt EGF. Further support for a high molecular weight EGF protein precursor has been provided (39) by structural studies of submandibular gland messenger-RNA encoding the propro-EGF which suggested that the precursor contains at least seven peptides with sequences similar to standard EGF. In the present study, we observed a single immunoreactive EGF component corresponding to standard EGF in neonatal urine. However, this does not exclude an EGF precursor or EGF-like peptides of different molecular size in tissues or urine. The development of specific RIA systems for EGF precursors may shed more light on the origin and the hormonal reguation of EGF of standard molecular weight during early stages of development.

Acknowledgments. The authors thank Ms. Thelma Macaso, Ms. H. Kim, and Ms. Uma Beri for skillful technical assistance, Drs. Jan Alm, Annette Grueters, and Steven B. Hoath for stimulation, and Ms. Sharon Schuler, Ms. Estelle Stanhill, and Ms. Arja Lehtonen for typing this manuscript.

\section{REFERENCES}

1. Adamson ED, Deller MJ, Warshaw JB 1981 Functional EGF receptors are present in mouse embryo tissues. Nature 291:656

2. Beardmore JM, Richards RC 1983 Concentrations of epidermal growth factor in mouse milk throughout lactation. J Endocrinol 96:287

3. Bower JM, Camble R, Gregory H, Gerring EL, Willshire IR 1975 Inhibition of gastric acid secretion by epidermal growth factor. Experientia 31:825

4. Byyny RL, Orth DA, Cohen S 1972 Radioimmunoassay of epidermal growth factor. Endocrinology 90:1261

5. Catterton WZ, Escobedo MB, Sexson WR, Gray ME, Sundell HW, Stahlman ML 1979 Effect of epidermal growth factor on lung maturation in fetal rabbits. Pediatr Res 13:104

6. Chabot JG, Payet N, Hugon JS 1983 Effects of epidermal growth factor (EGF) on adult mouse small intestine in vivo and in organ culture. Comp Biochem Physiol 74A:247

7. Chopra IJ 1972 A rapid radioimmunoassay for measurement of thyroxine in unextracted serum. J Clin Endocrinol Metab 34:938

8. Chopra IJ, Ho RS, Lam RW 1972 An improved radioimmunoassay of triiodothyronine in serum its application to clinical physiological studies. $\mathrm{J}$ Lab Clin Med 80:729

9. Cohen S 1962 Isolation of a mouse submaxillary gland protein accelerating incisor eruption and eyelid opening in newborn animals. J Biol Chem 237:1555

10. Cohen S 1965 Growth factors and morphogenic induction. In: MD Anderson Tumor Institute (ed) Developmental and Metabolic Control Mechanisms and Neoplasia, p 251. Williams and Wilkins Co, Baltimore

11. Covelli I, Rossi R, Mozzi R, Frati L 1972 Synthesis of bioactive ${ }^{13 !}$ I labeled epidermal growth factor and its distribution in rat tissues. Eur $\mathrm{J}$ Biochem 27:225

12. Dembinski A, Gregory H, Kontvrek S, Polanski M 1982 Trophic action of epidermal growth factor on the pancreas and gastroduodenal mucosa in rats. J Physiol 325:35

13. Farebrother DA, Mann CB 1970 The histological effects of epithelial growth factor and its antiserum in the neonatal rat. Proc Biochem Soc 118:33P

14. Frati L, Cenci, G, Sbaraglia G, Teti DV, Covelli I 1976 Levels of epiderma growth factor in mice tissues measured by a specific radioreceptor assay. Life Sci 18:905

15. Gospodarowicz D, Biolecki H, Thakral TK 1979 The angiogenic activity of fibroblast and epidermal growth factors. Exp Eye Res 28:501

16. Gray A, Dull TJ, Ullrich A 1983 Nucleotide sequence of epidermal growth factor cDNA predicts a 128,000 molecular weight protein precursor. Nature 303:722

17. Gregory H, Bower JM, Willshire IR 1978 Urogastrone and epidermal growt factor. In: Kastrup KW, Nielsen JH (eds) Growth Factors, p 75. Pergamon Press, Oxford

18. Gregory H, Willshire IR 1975 The isolation of the urogastrones-inhibitors of gastric acid secretion from human urine. Hoppe Seylers Z Physiol Chem 356:1765

19. Henry RJ 1964 Clinical Chemistry. Principles and Technics, p 266. Medical Division, Harper and Row Publishers, New York

20. Hirata Y, Orth DN 1979 Epidermal growth factor (urogastrone) in human fluids: size heterogeneity. J Clin Endocrinol Metab 48: 673

1. Hirata Y, Orth DN 1979 Concentrations of epidermal growth factor, nerve growth factor and submandibular gland renin in male and female mouse tissue and fluids. Endocrinology 105:1382

22. Hoath S, Lakshmanan J, Scott SM, Fisher DA 1983 Effect of thyroid hormones on epidermal growth factor concentration in neonatal mouse skin. Endocrinology $112: 308$

23. Ladda RL, Bullock L. Gianopoulos T, McCormick L 1979 Radioreceptor assay for epidermal growth factor. Anal Biochem 93:286

24. Lakshmanan J, Perheentupa J, Hoath SB, Kim H, Grueters A, Odell C, Fisher DA 1984 Epidermal growth factor (EGF) in mouse eye: effects of thyroxine, testosterone and exogenous EGF. Pediatr Res, in press

25. Lintern-Moore S, Moore GPM, Panaretto BA, Robertson D 1981 Follicular development in the neonatal mouse ovary. Effect of epidermal growth factor. Acta Endocrinol (Copenh) 96:123

26. Lowry OH, Rosebrough NJ, Farr AL, Randall RJ 1951 Protein measurement with the Folin phenol reagent. J Biol Chem 193:263

27. Matias JR, Orentreich N 1983 Stimulation of hamster sebaceous glands by epidermal growth factor. J Invest Dermatol 80:516

28. Moore GPN, Panarello BA, Robertson D 1981 Effects of epidermal growth factor on hair growth in the mouse. J Endocrinol 88:293

29. Murphy RA, Pantazis NJ, Papastavros M 1979 Epidermal growth factor and nerve growth factor in mouse saliva: a comparative study. Dev Biol 71:356

30. Nexo E Hollenberg MD, Figueroa A, Pratt RM 1980 Detection of epidermal growth factor-urogastrone and its receptor during fetal mouse development. Proc Natl Acad Sci USA 77:2782

31. Niall M, Ryan GB, McO'Brien N 1983 The effect of epidermal growth factor on wound healing in mice J Surg Res 33:164

32. Oka Y, Ghishan FK, Greene HL, Orth D 1983 Effect of mouse epidermal growth factor/urogastrone on the functional maturation of rat intestine. Endocrinology 112:940

33. O'Keefe E, Hollenberg MD, Cuatrecasas P 1974 Epidermal growth factor. Characteristics of specific binding in membranes from liver, placenta and other target tissues. Arch Biochem Biophys 164:518

34. Perheentupa J, Lakshmanan J, Hoath S, Kim H, Fisher DA 1983 Hormonal modulation of epidermal growth factor concentration in mouse serum and bile. In: Abstracts from the meeting of the Endocrine Society, 65th Annual Meeting San Antonio, Abstr 79

35. Roberts ML, Freston JA, Reade PC 1976 Suppression of immune responsiveness by a submandibular salivary gland factor. Immunology 30:811

36. Rodbard D, Munson PJ 1978 Radioimmunoassay data processing In: Rose NR, Friedman $\mathrm{H}$ (eds) Manual for Clinical Immunology, p 343. American Society for Microbiology, Washington, DC

37. Savage CR Jr, Cohen S 1972 Epidermal growth factor and a new derivative. Rapid isolation procedures and chemical characterization. J Biol Chem 247:7609

38. Scheving LA, Yeh YC, Tsai TH, Scheving LE 1979 Circadian phase development stimulatory effects of epidermal growth factor on deoxyribonucleic acid synthesis in the tongue, esophagus and stomach of the adult male mouse. Endocrinology 105:1475

39. Scott JM, Quiroga M, Sanchez-Pescador R, Fong N, Selby M, Rutter W, Bell GI 1983 Structure of a mouse submaxillary messenger RNA encoding epidermal growth factor and seven related proteins. Science 221:236

40. Smith RS, Smith LA, Rich L, Weimar V 1981 Effects of growth factors on corneal wound healing. Invest Ophthalmol Vis Sci 20:222

41. Starkey RH, Cohen S, Orth DN 1975 Epidermal growth factor. Identification of a new hormone in human urine. Science 18:800

42. Walker P, Weichsel ME Jr, Hoath SB, Poland RE, Fisher DA 1981 Effect of thyroxine, testosterone, and corticosterone on nerve growth factor (NGF) and epidermal growth factor (EGF) concentrations in female mouse submaxillary gland. Dissociation of NGF and EGF responses. Endocrinology 109:582 